\title{
Utilization of a novel activated carbon adsorbent from press mud of sugarcane industry for the optimized removal of methyl orange dye in aqueous solution
}

\author{
Dominic Justine G. Rondina ${ }^{1}$. Deanne V. Ymbong ${ }^{1}$ - Macvon Jovy M. Cadutdut ${ }^{1}$. Jhon Ray S. Nalasa ${ }^{1}$. \\ Jonas B. Paradero ${ }^{1}$ - Val Irvin F. Mabayo ${ }^{1}$ (D) Renato O. Arazo ${ }^{1,2}$
}

Received: 17 July 2019 / Accepted: 9 October 2019 / Published online: 15 October 2019

(c) The Author(s) 2019

\begin{abstract}
In this study, a novel activated carbon adsorbent from the press mud of a sugarcane industry was used to remove methyl orange dye (MOD) from aqueous solution and was optimized via response surface methodology using the central composite design. The adsorbent was characterized by FTIR and SEM analysis and showed the presence of functional groups such as alcohols, nitriles, amides, alkane, alkyl halides, and alkenes, and it also showed fibrous surface morphological appearance. The factors affecting MOD adsorption, such as initial concentration, adsorbent dose, and contact time were examined, and optimal $\mathrm{pH} 2.0$ to remove MOD in an aqueous solution that is found in various studies is also utilized. The results showed maximum MOD removal rate of $98.68 \%$ when the initial concentration, adsorbent dose, and contact time were optimally set as $24.17 \mathrm{mg} / \mathrm{L}, 0.5 \mathrm{~g}$, and $20 \mathrm{~min}$, respectively. The analysis of the equilibrium data revealed that MOD adsorption using press mud activated carbon best fitted the Langmuir isotherm $\left(R^{2}=0.96103\right)$ which implies monolayer adsorption process. Also, the kinetics of MOD adsorption using press mud activated carbon followed a pseudo-first-order model $\left(R^{2}=0.96096\right)$ which means that the active sites are proportional to the non-active sites during the adsorption process.
\end{abstract}

Keywords Adsorption $\cdot$ Methyl orange dye $\cdot$ Response surface methodology $\cdot$ Press mud $\cdot$ Activated carbon

\section{Introduction}

Nowadays, the annual global production of more than $7 \times 10^{5}$ tons of dyes annually (Mohammed et al. 2014), with approximately $10-15 \%$ of these dyes are being released in the environment during dyeing process, makes the effluent from the dye users industries highly colored and aesthetically unpleasant (Chincholi et al. 2014). Thus, it contributes to the pollution load. Dyes are human-made organic colorants used by various industries such as textile, painting, and cosmetics in manufacturing colored products. Most of these dyes contain aromatic rings in their structure (El Boujaady et al. 2014) that

Val Irvin F. Mabayo valmabayo@gmail.com

1 College of Engineering and Technology, University of Science and Technology of Southern Philippines, 9004 Claveria, The Philippines

2 International Affairs Office, University of Science and Technology of Southern Philippines, 9004 Claveria, The Philippines could be harmful to human life considering its mutagenic and carcinogenic properties (Rashed 2013). Even a little quantity of dye present in water may cause damage to kidneys, reproductive systems, and nervous systems (Bouaziz et al. 2015). One of the dyes present in industrial effluents is the methyl orange dye (MOD), a well-known anionic azo dye that is soluble in water. It is synthesized by the reaction of sulfanilic acid and sodium nitrate (Rattanapan et al. 2017) and the most commonly used substance in the dying process.

These kinds of dyes contain high BOD, COD, and suspended solids that affect aquatic life (Alam et al. 2015). Thus, it is essential to have effective treatments for the removal of dyes before discharging them into the environment (Munagapati et al. 2018).

In recent years, numerous methods are being used for the treatment of dye-contaminated effluents such as oxidation (Vincenzo Naddeo 2013), ion exchange (Skipton and Dvorak 2014), adsorption (Ayub and Khorasgani 2014), coagulation/ flocculation (Prakash et al. 2014), photodegradation (Iovino et al. 2017), anodic oxidation (Godini et al. 2013), ozone treatment (Nilsson 2015), and biological treatment (Alvarino et al. 
2018). However, adsorption was proven as one of the best methods for the removal of various dyes present in the water system (Bouaziz et al. 2015) considering its convenience, ease of operation, simple designs, and cost efficiency (Bhatnagar et al. 2015). In this regard, a lot of various adsorbents have been studied by researchers (Chincholi et al. 2014). Activated carbon is the most commonly used adsorbent in the adsorption process because of its excellent adsorption ability (Shakoor and Nasar 2017). However, the use of activated carbon has been limited because of its high cost (Dim 2013). To reduce the high costs, agricultural wastes and residues are used as a precursor for activated carbon (Ahmad et al. 2014). In fact, cherry kernels (Iakovleva et al. 2017), rice bran (Hong and Wang 2017), coir pith ash (Bahar et al. 2018), wheat straw (Lin et al. 2017), potato residue (Zhang et al. 2015), rice straw (Sangon et al. 2018), coconut coir dust (Etim et al. 2016), orange peels (Rožič et al. 2014), and wood apple shell (Sartape et al. 2017) among others have been used for dye removal in aqueous solutions in the recent literature. However, most of these contain low adsorption capacity. The need for other economical, eco-friendly, and highly efficient precursor for activated carbon is still desired. One of the precursors might be press mud.

Press mud is a compacted sugar industry waste manufactured during the filtration of cane juice. The press mud is generally utilized as a fertilizer, as these organic wastes can supply an adequate amount of plant nutrients to the soil. Due to its positive effects on the physical condition of the soil, the water holding capacity and aeration of the soil are enhanced. However, with the amounting thousands of tons of press mud produced annually, it has started to cause significant disposal problems for the sugar industry and the environment. Recently, the literature reveals that, so far, no considerable effort has been made to utilize press mud as a precursor for activated carbon.

In this present paper, the researchers have investigated the efficiency of activated carbon from press mud from the sugarcane industry in removing MOD in aqueous solution. The process was optimized through central composite design (CCD) of the RSM using Design Expert 7.0 software. Moreover, the optimal condition of $\mathrm{pH}$ from the recent literature has been utilized and the influence of various parameters such as initial concentration, adsorbent dosage, and contact time was investigated and had been optimized. Furthermore, the adsorption isotherms and kinetics are also under the scope of the investigation.

\section{Materials and methods}

\section{Adsorbent preparation}

The preparation of adsorbent was adapted from the study of de Luna et al. (de Luna et al. 2017) and Azme and Murshed
(Azme and Murshed 2018) with modifications. A sack of press mud was collected from Crystal Sugar Company, Inc. located at Maramag, Bukidnon, the Philippines. The $400 \mathrm{~g}$ of the collected press mud was dried in an oven for $90{ }^{\circ} \mathrm{C}$ for $12 \mathrm{~h}$. After that, it was crushed using mortar and pestle to pulverize the chunks and then sieved through $60 \mu \mathrm{m}$ mesh size. The obtained material was soaked in $2 \%(\mathrm{v} / \mathrm{v}) \mathrm{HNO}_{3}$ for $24 \mathrm{~h}$ at room temperature to activate the carbon from the press mud and enhance the adsorption capacity of the material. At the end of $24 \mathrm{~h}$, the excess $\mathrm{HNO}_{3}$ was filtered and the mixture was dried in a muffle furnace at $105^{\circ} \mathrm{C}$ for $2 \mathrm{~h}$ to remove moisture content and then carbonized at $400{ }^{\circ} \mathrm{C}$ for $3 \mathrm{~h}$ before washing with distilled water until $\mathrm{pH} 7$ is obtained. After that, the carbon was dried at $105^{\circ} \mathrm{C}$ for $6 \mathrm{~h}$. Finally, the activated carbon was stored in a desiccator until use for the adsorption experiments.

\section{Dye solution preparation}

MOD with a chemical structure shown in Fig. 1 was obtained from Himedia Laboratories, Mumbai, India. A stock solution of $1000 \mathrm{mg} / \mathrm{L}$ concentration was prepared by dissolving the $1 \mathrm{~g}$ of MOD powder in $1 \mathrm{~L}$ of distilled water inside a 1-L volumetric flask. The stock solution was diluted with distilled water to acquire desired MOD concentration.

The optimum $\mathrm{pH} 2.0$ that was published elsewhere was used in all experimental runs in the present work (Iakovleva et al. 2017). To achieve the desired optimal $\mathrm{pH}$ condition of 2.0 , the experiments were adjusted by $1 \mathrm{M} \mathrm{NaOH}$ or $1 \mathrm{M}$ $\mathrm{HCl}$ using $\mathrm{pH}$ meter (Hanna $\mathrm{pH}$ meter HI98129). To prepare the $1 \mathrm{M} \mathrm{NaOH}, 40 \mathrm{~g}$ of $\mathrm{NaOH}$ was added to $1 \mathrm{~L}$ distilled water. On the other hand, $83.33 \mathrm{~mL}$ of $37 \%$ concentrated $\mathrm{HCl}$ was added to $1 \mathrm{~L}$ of distilled water to prepare $1 \mathrm{M} \mathrm{HCl}$.

\section{Characterization of press mud activated carbon}

The physical and chemical properties of the powdered activated carbon from press mud were analyzed using FTIR and SEM techniques. The FTIR, as well as the SEM, were both analyzed and conducted at UP Diliman in Quezon City, the<smiles>CN(C)c1ccc(/N=N/c2ccc(S(=O)(=O)O[Na])cc2)cc1</smiles>

Fig. 1 MOD chemical structure 
Philippines. These determined the functional groups present in activated carbon from press mud and analyzed the surface morphology of activated carbon from press mud before the adsorption, respectively.

\section{Experimental design}

The RSM was applied to the study particularly CCD using Design Expert 7.0 software. The initial dye concentration and contact time were considered to be the most critical variables of the study (Chiou et al. 2003).

Experimental runs were conducted based on the parametric study principle of taking the center of one variable as constant and combining it to all ranges of the other variables to look for a peak in a graph once plotted. The experimental range and levels used in the parametric study are shown in Table 1.

The purpose of this stage is to explore the full range of reaction conditions to identify the optimum operating variables. Hence, the results were used during the adsorption of MOD in aqueous solution using press mud activated carbon. Furthermore, CCD of the Design Expert in the RSM was used to analyze the data that were gathered in the study statistically. Therefore, 20 runs were generated to achieve the optimum level given by CCD which are presented in Table 2 .

\section{Experimental procedure}

Adsorption experiments were performed as suggested by the design developed by the CCD of the RSM at Agrivironmental Laboratory at USTP-Claveria, the Philippines.

The procedure was adopted from Jawad et al. (2017) with modifications. The experiments were carried out in a 125 $\mathrm{mL}$ Erlenmeyer flask with the working volume of $50 \mathrm{~mL}$ of aqueous solution at optimal $\mathrm{pH}$ condition of 2.0. The desired amount of adsorbent dosage was put in the flask. Stirring was carried out using magnetic stirrer (VS-130SH). After that, the mixture was separated by filtration process through a filter paper (Whatman 5) after a specified period. A UVspectrophotometer examined the residual dye concentration at $464 \mathrm{~nm}$ wavelength (Azami et al. 2012). The final dye

Table 1 Experimental range and levels of independent variables in adsorption

\begin{tabular}{llllll}
\hline Factor & \multicolumn{2}{l}{ Coded level } \\
\cline { 2 - 6 } & -2 & -1 & 0 & 1 & 2 \\
\hline Adsorbent dose (g) & 0.25 & 0.5 & 0.75 & 1.0 & 1.25 \\
$\begin{array}{l}\text { Initial dye concentra- } \\
\text { tion (mg/L) }\end{array}$ & 10 & 15 & 20 & 25 & 30 \\
Contact time (min) & 10 & 20 & 30 & 40 & 50 \\
\hline
\end{tabular}

Table 2 Experimental runs generated by CCD in RSM

\begin{tabular}{|c|c|c|c|}
\hline Run & $\begin{array}{l}\text { Adsorbent dose } \\
\text { (g) }\end{array}$ & $\begin{array}{l}\text { Initial concentration } \\
(\mathrm{mg} / \mathrm{L})\end{array}$ & $\begin{array}{l}\text { Contact } \\
\text { time (min) }\end{array}$ \\
\hline 1 & 0.75 & 20 & 30 \\
\hline 2 & 0.50 & 15 & 20 \\
\hline 3 & 0.75 & 20 & 30 \\
\hline 4 & 0.75 & 20 & 30 \\
\hline 5 & 0.25 & 20 & 30 \\
\hline 6 & 0.75 & 10 & 30 \\
\hline 7 & 1.00 & 15 & 20 \\
\hline 8 & 0.75 & 20 & 30 \\
\hline 9 & 1.00 & 25 & 20 \\
\hline 10 & 0.75 & 20 & 30 \\
\hline 11 & 0.75 & 20 & 10 \\
\hline 12 & 0.75 & 20 & 50 \\
\hline 13 & 1.00 & 15 & 40 \\
\hline 14 & 0.50 & 15 & 40 \\
\hline 15 & 0.50 & 25 & 40 \\
\hline 16 & 1.00 & 25 & 40 \\
\hline 17 & 0.50 & 25 & 20 \\
\hline 18 & 0.75 & 20 & 30 \\
\hline 19 & 1.25 & 20 & 30 \\
\hline 20 & 0.75 & 30 & 30 \\
\hline
\end{tabular}

concentration was calculated using the predetermined calibration curve.

\section{Model fitting and optimization}

The percent removal of MOD was taken as a response of the experimental design and is calculated using Eq. 1:

$\mathrm{MOD} \%$ removal $=\frac{C_{0}-C_{\mathrm{e}}}{C_{0}} \times 100$,

where $C_{0}$ is the initial concentration of MOD in the solution $(\mathrm{mg} / \mathrm{L})$ and $C_{\mathrm{e}}$ is the final concentration of MOD in the solution $(\mathrm{mg} / \mathrm{L})$.

Analysis of variance (ANOVA) evaluated the statistical significance of the model for the response and corresponding $F$ values including values of Probability $>F$ (Prob. $>F$ ). For statistically significant model terms, the value of Prob. $>F$ should be less than 0.05 .

The effects of the experimental runs underwent graphical modeling to determine the interactive effects of the chosen operating variables. The 3D model was generated using the Design Expert 7.0 software. Thus, it was useful in showing an interaction of two factors and maintains the other factor at a fixed level. The 3D models are presented in "Results and discussion" section. 
In the optimization menu of the Design Expert 7.0 software, the desired goal for each factor and response was chosen. In order to determine the optimum values with the specified goal, the desired goals are in range (initial concentration), minimize (contact time, adsorbent dose), and maximize (percent MOD removal).

\section{Adsorption mechanism}

Isotherm runs were done using the optimal values of the adsorbent dose and contact time while varying initial concentration. All 5 runs were done at $\mathrm{pH}$ 2.0. The results were then fitted to Langmuir and Freundlich models using Eqs. 2 and 3 , respectively. The adsorption capacity was computed using Eq. 4:

$\frac{1}{Q_{\mathrm{e}}}=\left(\frac{1}{b Q_{0}}\right) \frac{1}{C_{\mathrm{e}}}+\frac{1}{Q_{0}}$,

$\ln Q e=\ln k f+\frac{1}{n} \ln C_{e}$,

$Q e=\frac{\left(C o-C_{e}\right) V}{M}$,

where $C_{0}$ and $C_{\mathrm{e}}$ are the initial and equilibrium concentrations (mg/L) of MOD, $Q_{\mathrm{e}}$ is the equilibrium capacity $(\mathrm{mg} / \mathrm{g})$, $Q_{\mathrm{o}}$ is the monolayer adsorption capacity of the adsorbent $(\mathrm{mg} / \mathrm{g}), b$ is the Langmuir constant $(\mathrm{L} / \mathrm{mg})$ which is related to adsorbent and adsorbate, $k f$ and $n$ are the adsorption Freundlich isotherm constants that affect the adsorption process such as adsorption capacity and intensity of adsorption, $m$ is the mass ( $\mathrm{g}$ ) of the adsorbent, and $V$ is the volume of the MOD solution (L).

In solving the parameters of Langmuir, a plot between $1 / C_{e}$ versus $1 / Q_{\mathrm{e}}$ was performed using Origin Pro 2017 software. From the graph, the slope of the graph is equal to $1 / Q_{0}$, and by deriving and calculating the variable, the $Q_{\text {o }}$ values were found. After plugging the values of $Q_{0}$, the values of $b$ was obtained. On the other hand, for solving the Freundlich parameters, a plot between $\ln C_{\mathrm{e}}$ versus $\ln Q_{\mathrm{e}}$ was carried out in Origin Pro 2017 software. From the graph, the value of $1 / n$ is equal to the slope while the value of $\ln k f$ is equal to the intercept of the graph. After that, by taking the natural exponential function of both sides, the value of $k$ was obtained. The highest $R^{2}$ value determines the mostfitted isotherm model. The model is presented in "Results and discussion" section.

In kinetic modeling, the optimal values of adsorbent dose and initial dye concentration generated by CCD with optimum condition of $\mathrm{pH} 2.0$ were used with varying contact time to determine whether the pseudo-first-order or pseudo-second-order model best explains the adsorption mechanism. The linear forms of the pseudo-first-order and pseudo-second-order kinetic models are shown in Eqs. 5 and 6 , respectively.

$\ln C_{t}=\ln C_{0}-k_{1} t$,

$\frac{1}{C_{t}}=\frac{1}{C_{0}}+k_{2} t$

where $C_{0}$ is the initial concentration of MOD $(\mathrm{mg} / \mathrm{L}), C_{t}$ is the concentration of reaction time $(\mathrm{mg} / \mathrm{L}), t$ is the contact time ( $\mathrm{min}), K_{1}$ is the first-order rate constant $\left(\mathrm{h}^{-1}\right)$, and $K_{2}$ is the rate constant of second order $(\mathrm{min} / \mathrm{L})$.

A plot of $\operatorname{lnC}_{\mathrm{t}}$ versus $t$ (min) was performed using Origin Pro 2017 software to enhance the quality of the graph. The $-K_{1}$ and $Q_{\mathrm{e}}$ values were calculated from the slope and intercept. On the other hand, a linear graph of $1 / C_{t}$ versus $t$ (min) was plotted to determine the pseudo-second-order constants. From the graph, the values of $K_{2}$ and $Q_{\mathrm{e}}$ were obtained from the slope and intercept, respectively. The highest $R^{2}$ value determines the best kinetic model. The model is presented in "Results and discussion" section.

\section{Results and discussion}

\section{Physical and chemical properties of PAC}

The morphological structure and properties of the press mud activated carbon (PAC) have been characterized by SEM analysis, and the images are presented in Fig. 2. It can be seen in Fig. 2a that the carbon has a fibrous appearance that can be associated with the sugarcane biomass where the press mud was derived from. Figure $2 b$ is the carbon image at $50 \mu \mathrm{m}$ magnification, exhibiting clear fibrous structure. Figure $2 \mathrm{c}$, at $5 \mu \mathrm{m}$ magnification, is where the carbon begins to show its micropores where the dyes could be trapped and adsorbed.

Microspores are very important in attracting water contaminant, since particles can be trapped in the pores (Azme and Murshed 2018). Figure $2 d$ shows where the carbon is at $2 \mu \mathrm{m}$ magnification and exhibiting clear uneven crater-like micropores in the adsorbent. The profuse layering structure of the pores is suggestive of the expected adsorption of MOD onto the surface of the adsorbent (Tizo et al. 2018).

The Fourier transform infrared spectroscopy (FTIR) analysis was used to predict the functional groups present in an adsorbent material. In this study, the FTIR spectrum of press mud activated carbon is presented in Fig. 3 and summarized in Table 3.

From Table 3, the wavelength of PAC ranges $3700-3200 \mathrm{~cm}^{-1}$ with an actual peak at $3628.1 \mathrm{~cm}^{-1}$ 

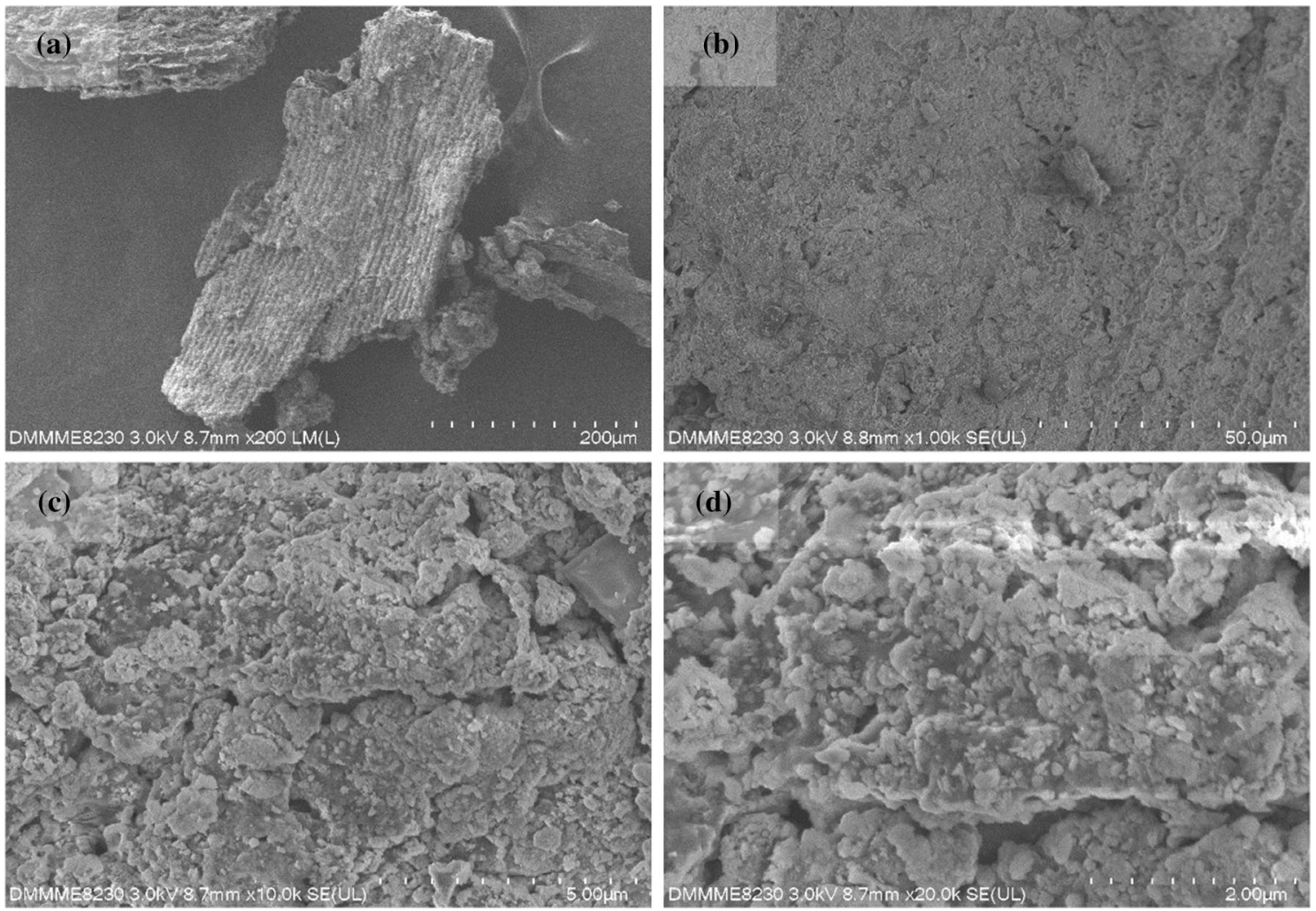

Fig. 2 SEM images of PAC at a $200 \mu \mathrm{m}, \mathbf{b} 50 \mu \mathrm{m}, \mathbf{c} 5 \mu \mathrm{m}$, and d $2 \mu \mathrm{m}$

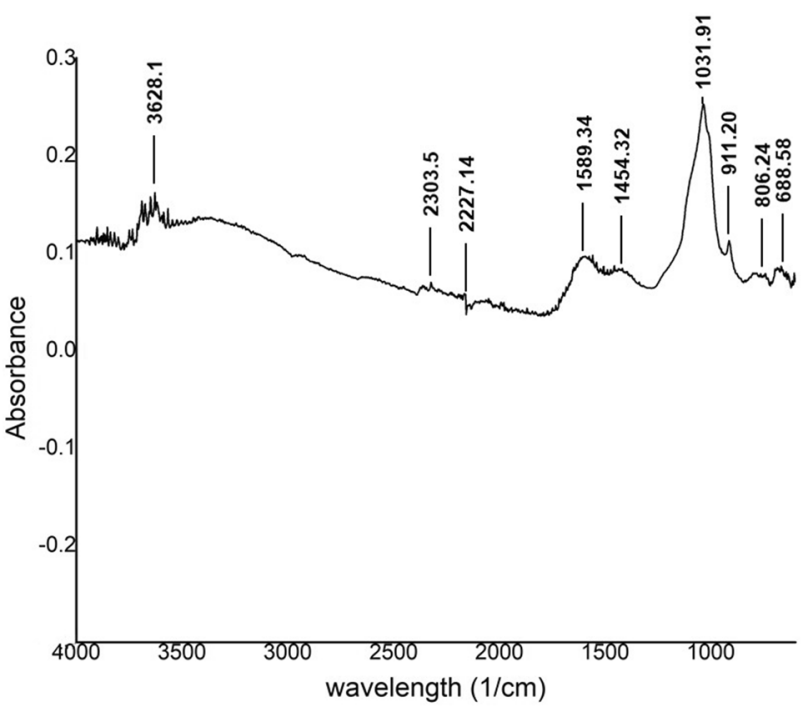

Fig. 3 FTIR spectrum of PAC

indicated the presence of broad silanol groups that has $\mathrm{O}-\mathrm{H}$ stretch of alcohol. The stretch of nitrile groups is observed in the peaks of $2303.5 \mathrm{~cm}^{-1}$ and $2227.4 \mathrm{~cm}^{-1}$. The amino group is shown in the $\mathrm{N}-\mathrm{H}$ bending at ranges $1600-1555 \mathrm{~cm}^{-1}$ with an actual peak at $1589.34 \mathrm{~cm}^{-1}$.
Alkyl group is evident in the bending of $\mathrm{C}-\mathrm{H}$ at the peak of $1454.32 \mathrm{~cm}^{-1}$. A strong peak at $1031.91 \mathrm{~cm}^{-1}$ indicated the presence of alkyl halides and alkenes at the region of $920-820 \mathrm{~cm}^{-1}$. The IR spectra indicated strong and weak peaks at $911.20 \mathrm{~cm}^{-1}, 806.24 \mathrm{~cm}^{-1}$, and $688.58 \mathrm{~cm}^{-1}$ which are associated with $\mathrm{CH}$-bending. Similar functional groups were found in the study of Kumar and Tamilarasan (2013). Research works of Nandini (Nandini and Vishalakshi 2012) and Hakumar et al. (Harikumar et al. 2013) studied the IR spectra of MOD, and functional groups such as alkenes, amides, and nitriles were observed. Alkenes are nonpolar while amides and nitriles are polar. While in PAC, polar and nonpolar covalent bonds were also observed such as silanol, alkyl halides, and alkane. Since similar functional groups and covalent bonds were found on PAC, these may imply that the PAC has capability to attract and bind MOD. Furthermore, the high content of carbon that is derived from press mud can also help in the adsorption process (Azme and Murshed 2018).

\section{Methyl orange dye removal using PAC}

The experimentation was carried out according to the CCD experimental design shown in Table 4. The statistical results were produced through the values modeled 
Table 3 FTIR functional groups of the PAC

\begin{tabular}{|c|c|c|c|}
\hline \multirow[t]{2}{*}{ Functional group } & \multicolumn{2}{|c|}{ Wavelength peak $\left(\mathrm{cm}^{-1}\right)$} & \multirow[t]{2}{*}{ Bond } \\
\hline & Range & Actual & \\
\hline Silanol (alcohol) & $3700-3200$ & 3628.1 & $\mathrm{O}-\mathrm{H}$ stretch \\
\hline 1,3 Aryl subs. isocyanate (nitriles) & $2305-2235$ & 2303.5 & $\mathrm{C}=\mathrm{N}$ stretch \\
\hline 3-Aryl substituted (nitriles) & $2290-2205$ & 2227.4 & $\mathrm{C} \equiv \mathrm{N}$ stretch \\
\hline Aromatic amino acid (amides) & $1600-1555$ & 1589.34 & $\mathrm{~N}-\mathrm{H}$ bend \\
\hline Aliphatic anhydride (alkane/alkyl) & $1470-1425$ & 1454.32 & $\mathrm{C}-\mathrm{H}$ bend \\
\hline Alkyl halides & $1090-1020$ & 1031.91 & C-F stretch \\
\hline Alkenes & $920-820$ & 911.20 & $=\mathrm{C}-\mathrm{H}$ bend \\
\hline Unsaturated hydrocarbon (alkane/alkyl) & $855-785$ & 806.24 & $\mathrm{C}-\mathrm{H}$ bend \\
\hline Tertiary amine hydrochloride (alkane/alkyl) & $850-680$ & 688.58 & $\mathrm{C}-\mathrm{H}$ bend \\
\hline
\end{tabular}

Table 4 Percent removal of MOD using PAC

\begin{tabular}{|c|c|c|c|c|}
\hline \multirow[t]{2}{*}{ Run } & \multicolumn{3}{|l|}{ Operating variable } & \multirow[t]{2}{*}{ Removal (\%) } \\
\hline & $\begin{array}{l}\text { Initial MOD con- } \\
\text { centration }(\mathrm{mg} / \mathrm{L})\end{array}$ & $\begin{array}{l}\text { Adsorbent } \\
\text { dose }(\mathrm{g})\end{array}$ & $\begin{array}{l}\text { Contact } \\
\text { time (min) }\end{array}$ & \\
\hline 1 & 20 & 0.75 & 30 & 98.64 \\
\hline 2 & 15 & 0.50 & 20 & 89.76 \\
\hline 3 & 20 & 0.75 & 30 & 95.83 \\
\hline 4 & 20 & 0.75 & 30 & 98.64 \\
\hline 5 & 20 & 0.25 & 30 & 88.81 \\
\hline 6 & 10 & 0.75 & 30 & 86.05 \\
\hline 7 & 15 & 1.00 & 20 & 93.51 \\
\hline 8 & 20 & 0.75 & 30 & 98.64 \\
\hline 9 & 25 & 1.00 & 20 & 96.67 \\
\hline 10 & 20 & 0.75 & 30 & 97.24 \\
\hline 11 & 20 & 0.75 & 10 & 93.03 \\
\hline 12 & 20 & 0.75 & 50 & 95.13 \\
\hline 13 & 15 & 1.00 & 40 & 94.44 \\
\hline 14 & 15 & 0.50 & 40 & 90.70 \\
\hline 15 & 25 & 0.50 & 40 & 94.42 \\
\hline 16 & 25 & 1.00 & 40 & 97.23 \\
\hline 17 & 25 & 0.50 & 20 & 94.42 \\
\hline 18 & 20 & 0.75 & 30 & 97.94 \\
\hline 19 & 20 & 1.25 & 30 & 96.54 \\
\hline 20 & 30 & 0.75 & 30 & 96.75 \\
\hline
\end{tabular}

by response surface methodology via Design Expert 7.0 software. As presented in the table, the percent removal of MOD in aqueous solution using PAC ranges from 86.05 to $98.64 \%$.

\section{Predictive model of MOD adsorption using PAC}

The CCD suggested a quadratic model to the most fitted in predicting the removal of MOD through adsorption. Table 5 proves the statistical analysis of the suitability of the quadratic model through ANOVA.
The $R^{2}$ value of 0.9567 is high which signifies that the model in predicting the percent removal is accurate. This also means that it is $95.67 \%$ sure that the generated model can explain the variable of the data. The surface quadratic model equation (Eq. 7) is based on the actual factors generated by Design Expert 7.0.

$$
\begin{aligned}
y= & 31.40+3.31 A+42.12 B+0.65 C-0.24 A B-0.00328 A C \\
& +0.03 B C-0.06 A^{2}-20.74 B^{2}-0.00945 C^{2},
\end{aligned}
$$

where $y$ is the predicted percent dye removal of MOD adsorb in water and $A, B$, and $C$ are the parameters given as initial concentration $(\mathrm{mg} / \mathrm{L})$, adsorbent dose $(\mathrm{g})$, and contact time (min), respectively.

From the equation, if the initial dye concentration $(A)$ alone increases, the dye removal increases since the equation has a positive coefficient. As similar to $A$, the adsorbent dose $(B)$ and contact time $(C)$ alone increases, it may result in higher percent removal of MOD. However, when $A, B$, and $C$ interacted with one another, one variable may favor to a higher percent removal while others may not. The interaction between $A$ and $B$ does not favor to a higher MOD removal since the value has a negative coefficient. Similar interaction was observed between $A$ and $C$ with both variables are combined and it may also result in lower percent removal. On the other hand, the interaction between $B$ and $C$ were favorable for higher percent removal since the value has a positive coefficient. Furthermore, when the values of $A, B$, and $C$ are squared in the model, it employed that the percent removal decreases since it showed a negative coefficient. Hence, the equation showed that there were antagonistic and synergistic effects if different variables are combined. Therefore, it is important to consider the variables since it imposes a positive or negative result in the percent removal of MOD.

Using the CCD established Eq. 7, the results of the actual runs were validated as shown in Table 6 . The $F$ value model of 24.53 implies that the model is significant. This implied that the model $p$ value $<0.0001$ was significant. In this case, $A, B, A^{2}, B^{2}$, and $C^{2}$ are significant models and there was 
Table 5 ANOVA for MOD removal surface quadratic model

\begin{tabular}{lccccc}
\hline Source & Sum of squares & $d f$ & Mean square & $F$ value & $\begin{array}{l}P \text { value } \\
\text { Prob }>F\end{array}$ \\
\hline Model & 226.83 & 9 & 25.20 & 24.53 & $<0.0001^{\mathrm{a}}$ \\
$A$-initial concentration & 79.76 & 1 & 79.76 & 77.65 & $<0.0001^{\mathrm{a}}$ \\
$B$-adsorbent dose & 48.95 & 1 & 48.95 & 47.65 & $<0.0001^{\mathrm{a}}$ \\
$C$-contact time & 2.76 & 1 & 2.76 & 2.69 & $0.1322^{\mathrm{b}}$ \\
$A B$ & 0.74 & 1 & 0.74 & 0.72 & $0.4158^{\mathrm{b}}$ \\
$A C$ & 0.21 & 1 & 0.21 & 0.21 & $0.6574^{\mathrm{b}}$ \\
$B C$ & 0.039 & 1 & 0.039 & 0.038 & $0.8486^{\mathrm{b}}$ \\
$A^{2}$ & 65.50 & 1 & 65.50 & 63.76 & $<0.0001^{\mathrm{a}}$ \\
$B^{2}$ & 42.24 & 1 & 42.24 & 41.12 & $<0.0001^{\mathrm{a}}$ \\
$C^{2}$ & 22.46 & 1 & 22.46 & 21.86 & $0.0009^{\mathrm{a}}$ \\
Lack of fit & 3.95 & 5 & 0.79 & 0.62 & $0.6911^{\mathrm{b}}$ \\
\hline
\end{tabular}

$R^{2}=0.9567$

${ }^{\mathrm{a}}$ Significant; ${ }^{\mathrm{b}}$ Not significant
Table 6 Actual versus predicted MOD removal percentages

\begin{tabular}{|c|c|c|c|c|c|}
\hline \multirow[t]{2}{*}{ Run } & \multicolumn{3}{|c|}{ Operating variable } & \multicolumn{2}{|c|}{ Percent removal } \\
\hline & $\begin{array}{l}\text { Initial con- } \\
\text { centration } \\
(\mathrm{mg} / \mathrm{L})\end{array}$ & $\begin{array}{l}\text { Absorbent } \\
\text { dose }(\mathrm{g})\end{array}$ & $\begin{array}{l}\text { Contact } \\
\text { time } \\
(\min )\end{array}$ & Actual value & $\begin{array}{l}\text { Predicted } \\
\text { value }\end{array}$ \\
\hline 1 & 20 & 0.75 & 30 & 98.64 & 97.80 \\
\hline 2 & 15 & 0.50 & 20 & 89.76 & 89.15 \\
\hline 3 & 20 & 0.75 & 30 & 95.83 & 97.80 \\
\hline 4 & 20 & 0.75 & 30 & 98.64 & 97.80 \\
\hline 5 & 20 & 0.25 & 30 & 88.81 & 89.12 \\
\hline 6 & 10 & 0.75 & 30 & 86.05 & 86.88 \\
\hline 7 & 15 & 1.00 & 20 & 93.51 & 93.12 \\
\hline 8 & 20 & 0.75 & 30 & 98.64 & 97.80 \\
\hline 9 & 25 & 1.00 & 20 & 96.67 & 97.30 \\
\hline 10 & 20 & 0.75 & 30 & 97.24 & 97.80 \\
\hline 11 & 20 & 0.75 & 10 & 93.03 & 93.19 \\
\hline 12 & 20 & 0.75 & 50 & 95.13 & 94.85 \\
\hline 13 & 15 & 1.00 & 40 & 94.44 & 94.42 \\
\hline 14 & 15 & 0.50 & 40 & 90.70 & 90.17 \\
\hline 15 & 25 & 0.50 & 40 & 94.42 & 94.92 \\
\hline 16 & 25 & 1.00 & 40 & 97.23 & 97.95 \\
\hline 17 & 25 & 0.50 & 20 & 94.42 & 94.56 \\
\hline 18 & 20 & 0.75 & 30 & 97.94 & 97.80 \\
\hline 19 & 20 & 1.25 & 30 & 96.54 & 96.12 \\
\hline 20 & 30 & 0.75 & 30 & 96.75 & 95.81 \\
\hline
\end{tabular}

only $0.01 \%$ chance of performing an error in predicting the MOD percent removal via PAC using the model. Furthermore, using the surface quadratic model equation in predicting the MOD percent removal via PAC was $99.99 \%$ reliable. While the insignificant terms are the values obtaining a $p$ value of $>0.05$ including the lack of fit $p$ value. The nonsignificant lack of fit confirms the applicability of the surface quadratic model to the response.

\section{Effects of initial concentration, adsorbent dose, and time on MOD removal}

The different effect of the operating parameters to the MOD adsorption and removal was validated by varying the initial concentration $(10-30 \mathrm{mg} / \mathrm{L})$, adsorbent dose $(0.25-1.25 \mathrm{~g})$, contact time (10-50 min), and using the optimal $\mathrm{pH}$ of 2.0. The ANOVA 3D model graph result implies that initial concentration, adsorbent dose, and contact time have a significant effect on the removal and adsorption of MOD efficiency. The effects of the parameters are more explained in Fig. 4.

Figure 4a shows the three-dimensional response surface methodology between initial concentration and adsorbent dose at optimum $\mathrm{pH} 2$, and the effect of initial concentration and adsorbent dose in the MOD percent removal was evaluated in ranges $15-25 \mathrm{ppm}$ and $0.50-1 \mathrm{~g}$.

The ANOVA model graph result implies that the percent removal increased with increasing MOD concentration and adsorbent dose. In higher concentration from 20 to $25 \mathrm{mg} / \mathrm{L}$, the percent removal was slower; this may employ that the availability of active sites on the surface of the adsorbent is becoming lower (Kumar and Tamilarasan 2013). Meanwhile, the rapid increase in percent removal as adsorbent dose increases from 0.50 to $0.75 \mathrm{~g}$ is due to the availability of the adsorption sites on the surface of the adsorbent where the dye molecules can be trapped (Lin et al. 2017).

Figure $4 \mathrm{~b}$ shows the three-dimensional response surface methodology between adsorbent dose and contact time in the MOD percent removal in ranges $0.50-1 \mathrm{~g}$ and $20-40 \mathrm{~min}$. The ANOVA model graph result implies

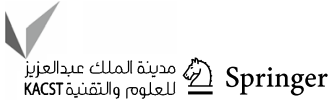



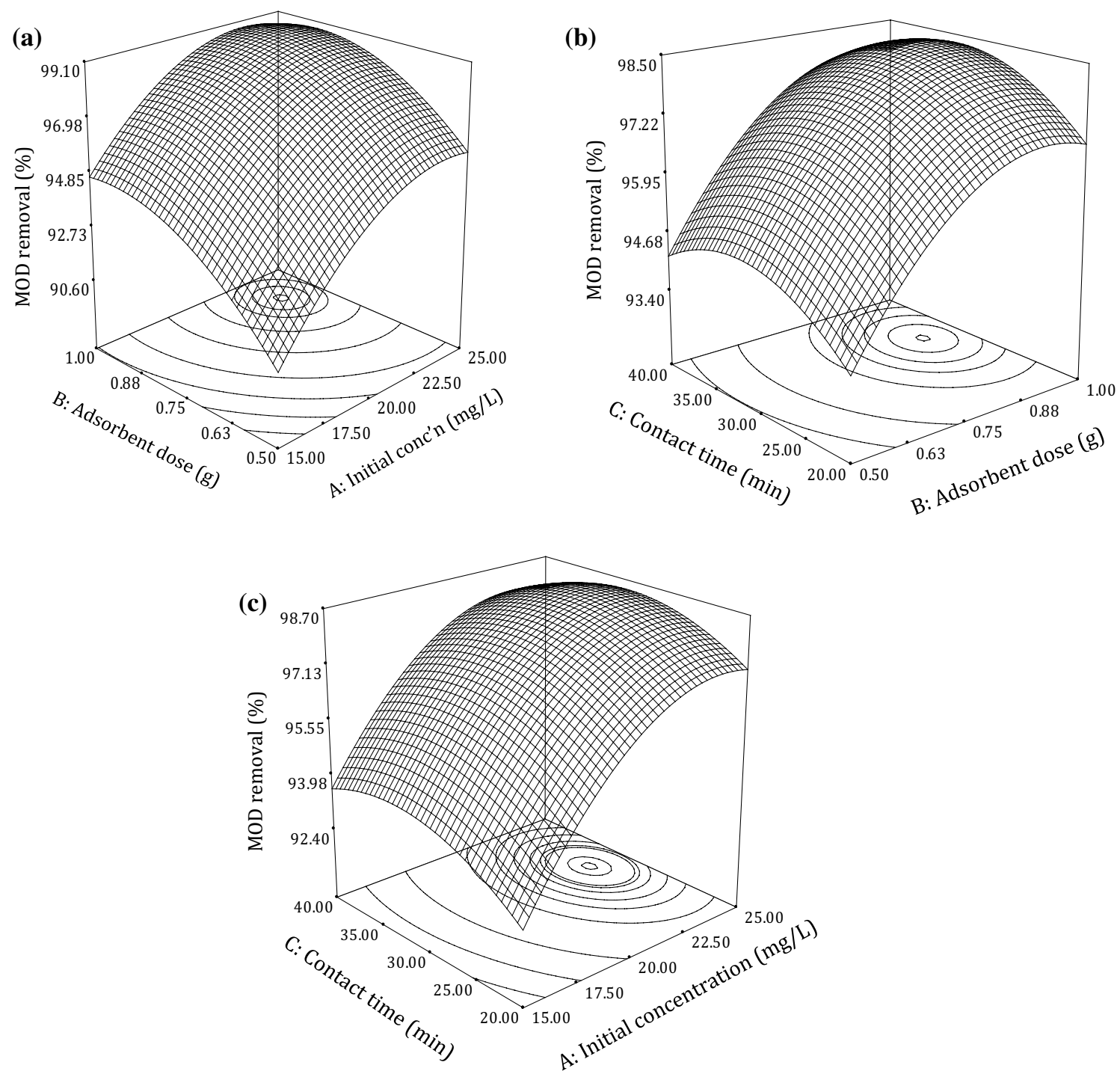

Fig. 4 3D response surface showing interactive effects of chosen variables in MOD removal

that the increase in adsorbent dose and initial concentration means an increase in the percent removal during the adsorption process. As the contact time increases from 30 to $35 \mathrm{~min}$, there is a gradual decrease in removal efficiency; this may due to the decrease in adsorption sites, and at $30 \mathrm{~min}$, it already reaches adsorption equilibrium (Rao et al. 2011). On the other hand, as the adsorbent dose increase from 0.88 to $1 \mathrm{~g}$, there is only slight difference in percent removal observed due to the interaction of the particles in bulk phase (Mi-na et al. 2006).

Figure $4 \mathrm{c}$ shows the three-dimensional response surface methodology between initial concentration and contact time in the MOD percent removal. The ANOVA model graph result implies that the increase in initial concentration and contact time means an increase in the percent removal during the adsorption process. At lower contact time, from 20 to $30 \mathrm{~min}$, the adsorption was rapid since the equilibrium time for the adsorption process has not been reached (Priyantha et al. 2015). On the other hand, at higher concentration from 22.50 to $25 \mathrm{mg} / \mathrm{L}$, the dye uptake gradually decreases; this is due to accumulation of dye adsorbate which lead to the diffusion of dyes in the solution which made the adsorption removal slower (Bouaziz et al. 2015).

\section{Optimized conditions for MOD removal through PAC}

The optimization was conducted in order to verify the maximum percent removal efficiency suggested by the $\mathrm{CCD}$ along with the best conditions of variables. The optimum parameter values were generated by the optimized conditions. 
The optimum values generated was $24.17 \mathrm{ppm}$ initial concentration, $0.5 \mathrm{~g}$ of adsorbent dose, and $20 \mathrm{~min}$ contact time having the optimum predicted value percent removal of $94.60 \%$ (Table 7). With the optimum values of the operating parameters, actual verification runs were conducted which resulted in $98.68 \%$ removal.

The verification run achieved a close result having a percent error value of $4.31 \%$ from the predicted value of $94.60 \%$ and an actual value of $98.68 \%$. This means that the percentage error is $4.31 \%$, and the percentage error is acceptable since it reached a result that is less than 5\% through the independent variables. This high MOD percent removal is comparable to that in the study by Haldorai and Shim (2014) of 98\% removal efficiency using chitosan $/ \mathrm{MgO}$ composite adsorbent and higher to that of the study by Lu et al. (2016) of more than $92 \%$ using NiFe-layered double hydroxides (LDHs). The adsorption capacity $\left(Q_{\mathrm{e}}\right)$ was obtained by using the optimum values generated by CCD. The adsorption capacity of the adsorbent at optimum conditions for MOD removal using PAC was $23.89 \mathrm{mg} / \mathrm{g}$. This implies that $23.89 \mathrm{mg} / \mathrm{g}$ of MOD in the aqueous solution is adsorbed by $1 \mathrm{~g}$ of PAC.

Table 7 MOD removal via adsorption optimization and validation

\begin{tabular}{|c|c|c|c|c|}
\hline \multirow[t]{2}{*}{ Experiment } & \multicolumn{3}{|l|}{ Variable } & \multirow{2}{*}{$\begin{array}{l}\text { MOD removal } \\
(\%)\end{array}$} \\
\hline & $\begin{array}{l}\text { Initial con- } \\
\text { centration } \\
(\mathrm{ppm})\end{array}$ & $\begin{array}{l}\text { Adsorbent } \\
\text { dose }(\mathrm{g})\end{array}$ & $\begin{array}{l}\text { Contact } \\
\text { time } \\
(\mathrm{min})\end{array}$ & \\
\hline CCD & 24.17 & 0.5 & 20 & 94.60 \\
\hline Validation & 24.17 & 0.5 & 20 & $98.68 \pm 0.33$ \\
\hline
\end{tabular}

Optimization criteria: in range initial concentration $(15-25 \mathrm{mg} / \mathrm{L})$; minimize adsorbent dose and contact time; maximize MOD removal

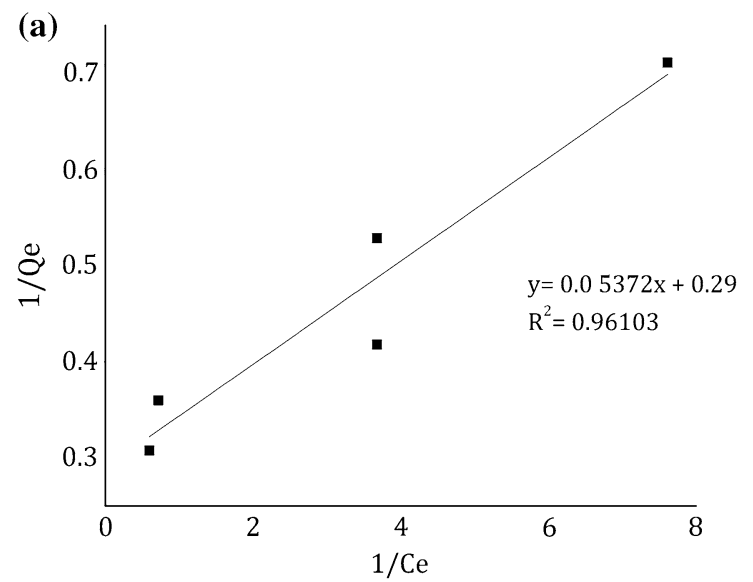

\section{Most-fitted isotherm model for MOD removal via adsorption}

The most-fitted isotherm model was evaluated via experimental runs under optimum conditions of $0.50 \mathrm{~g}$ of adsorbent, 20 min contact time, and varying the MOD concentration of $14.17,19.17,24.17,29.17$, and $34.17 \mathrm{mg} / \mathrm{L}$. The plot of Langmuir and Freundlich isotherms is shown in Fig. 5 and isotherm constants are summarized in Table 8 .

From the table, the Langmuir isotherm model is the best-fitted isotherm model having $R^{2}=0.96103$ compared to the Freundlich isotherm model having $R^{2}=0.919$. This implies that the adsorption process follows monolayer adsorption on the surface of the adsorbent (Priyantha et al. 2015), and the force of attraction existing between adsorbate and adsorbent is physisorption or also called Van der Waals forces which implies that the attraction between adsorbate and adsorbent are weak (Chiou et al. 2003).

\section{Mechanism of adsorption via kinetic model}

Figure 6 shows the result of the kinetic model experimental runs. Determination of the most-fitted kinetic model was conducted through kinetic model experimental runs under the optimum conditions of the MOD initial concentration of $24.17 \mathrm{ppm}$, an adsorbent dose of $0.5 \mathrm{~g}$, and varying the

Table 8 Isotherm model constants and correlation coefficients

\begin{tabular}{|c|c|c|c|}
\hline \multicolumn{2}{|l|}{ Langmuir } & \multicolumn{2}{|c|}{ Freundlich } \\
\hline Variable & Value & Variable & Value \\
\hline$b(\mathrm{mg})$ & 64.22 & $1 / n$ & 0.27041 \\
\hline$Q_{\mathrm{o}}(\mathrm{mg} / \mathrm{g})$ & 0.29 & $K_{\mathrm{f}}$ & 2.5978 \\
\hline$R^{2}$ & 0.96103 & $R^{2}$ & 0.919 \\
\hline
\end{tabular}

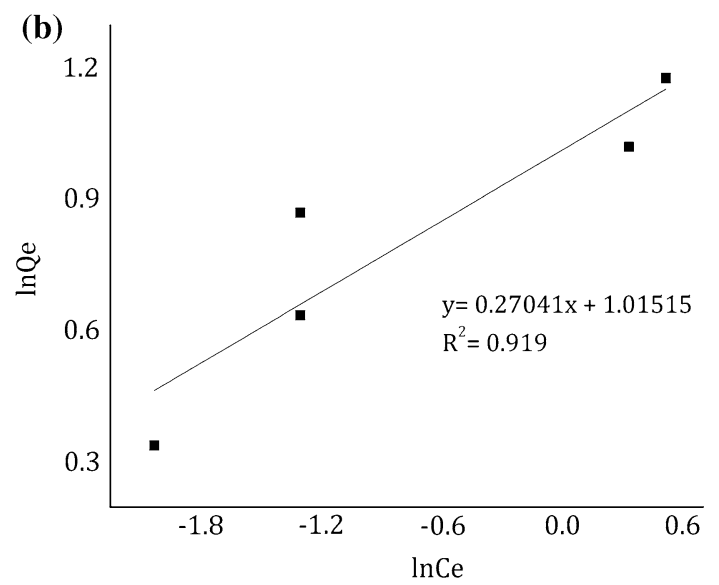

Fig. 5 Isotherm plots of a Langmuir and $\mathbf{b}$ Freundlich models 

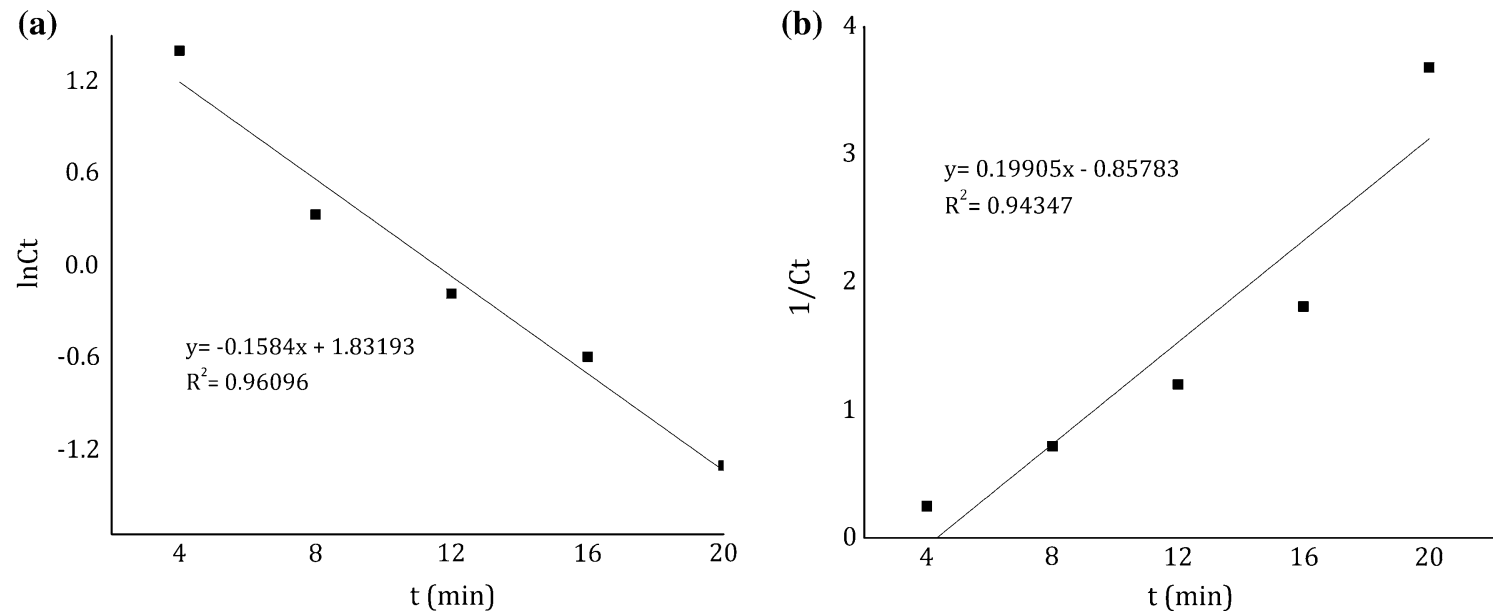

Fig. 6 Kinetic model plots of a pseudo-first order and $\mathbf{b}$ pseudo-second order

Table 9 Kinetic model constants and correlation coefficients

\begin{tabular}{lrllr}
\hline First order & & & \multicolumn{2}{l}{ Second order } \\
\cline { 5 - 5 } \cline { 5 - 5 } Variable & Value & & Variable & Value \\
\hline$K_{1}\left(\mathrm{~min}^{-1}\right)$ & -0.1584 & & $K_{2}(\mathrm{~min} / \mathrm{L})$ & 0.19905 \\
$\ln C_{0}$ & 1.83193 & & $1 / C_{0}(\mathrm{mg} / \mathrm{L})$ & -0.85783 \\
$R^{2}$ & 0.96096 & & $R^{2}$ & 0.94347 \\
\hline
\end{tabular}

contact time of $20 \mathrm{~min}$. The kinetic constants are summarized in Table 9.

From Table 9, the pseudo-first order best describes the adsorption mechanism having an $R^{2}$ value of 0.96096 rather than pseudo-second order with $R^{2}$ value of 0.94347 . This implies that the rate of adsorption by the active sites is proportional to the non-active sites (Crini and Badot 2008) and the type of reaction is directly proportional to the concentration of the reactants (Lin et al. 2017).

\section{Conclusion}

The study was conducted to remove the methyl orange dye (MOD) contaminant from aqueous solution through press mud activated carbon (PAC) via adsorption. The press mud activated carbon has a considerable number of micropores responsible for the removal of MOD up to $98.68 \%$. Various functional groups were found on PAC, such as alcohols, nitriles, amides, alkane, alkyl halides, and alkenes. With similar functional groups and covalent bonds on both PAC and MOD, the PAC has the capability to attract and bind MOD and proceed with the adsorption process. The removal of MOD contaminant from aqueous solution through activated carbon can be predicted through a significant quadratic model. The $3 \mathrm{D}$ surface ANOVA model graph implies that the increase in adsorbent dose and initial concentration resulted in an increase in percent removal of MOD. However, contact time had minimal effect. Optimum MOD removal of $98.68 \%$ can be achieved at 24.17 ppm initial concentration, $0.5 \mathrm{~g}$ of adsorbent dose, and 20 min contact time. Adsorption mechanism is explained by the most-fitted Langmuir isotherm $\left(R^{2}=0.96103\right)$ and pseudo-first-order kinetic model $\left(R^{2}=0.96096\right)$ implying that the adsorption happened in monolayer and in physisorption whereby active sites is proportional to the non-active sites during the adsorption process.

Funding This study received no funding.

\section{Compliance with ethical standards}

Conflict of interest The authors declare that they have no conflict of interest.

Open Access This article is distributed under the terms of the Creative Commons Attribution 4.0 International License (http://creativeco mmons.org/licenses/by/4.0/), which permits unrestricted use, distribution, and reproduction in any medium, provided you give appropriate credit to the original author(s) and the source, provide a link to the Creative Commons license, and indicate if changes were made.

\section{References}

Ahmad MA, Bello OS, Ahmad MA (2014) Adsorption studies of remazol brilliant blue $\mathrm{R}$ dye on activated carbon prepared from corncob. Columbia Int Publ Am J Mod Chem Eng 1:1-12

Alam MS, Khanom R, Rahman MA (2015) Removal of congo red dye from industrial wastewater by untreated sawdust. Am J Environ Prot 4:207-213. https://doi.org/10.11648/j.ajep.20150405.12

Alvarino T, Suarez S, Lema J, Omil F (2018) Understanding the sorption and biotransformation of organic micropollutants in 
innovative biological wastewater treatment technologies. Sci Total Environ 615:297-306. https://doi.org/10.1016/j.scito tenv.2017.09.278

Ayub S, Khorasgani FC (2014) Adsorption process for wastewater treatment by using coconut shell. J Environ Manage 4:1-8

Azami M, Bahram M, Nouri S, Naseri A (2012) Central composite design for the optimization of removal of the azo dye, methyl orange, from waste water using fenton reaction. J Serbian Chem Soc 77:235-246. https://doi.org/10.2298/JSC110315165A

Azme M, Murshed F (2018) Treatability of stabilize landfill leachate by using pressmud ash as an adsorbent. IOP Conf Ser Earth Environ Sci 140:12-41

Bahar MM, Mahbub KR, Naidu R, Megharaj M (2018) As(V) removal from aqueous solution using a low-cost adsorbent coir pith ash: equilibrium and kinetic study. Environ Technol Innov 9:198-209. https://doi.org/10.1016/j.eti.2017.12.005

Bhatnagar A, Sillanpää M, Witek-Krowiak A (2015) Agricultural waste peels as versatile biomass for water purification: a review. Chem Eng J 270:244-271. https://doi.org/10.1016/j.cej.2015.01.135

Bouaziz F, Koubaa M, Kallel F et al (2015) Efficiency of almond gum as a low-cost adsorbent for methylene blue dye removal from aqueous solutions. Ind Crops Prod 74:903-911. https://doi. org/10.1016/j.indcrop.2015.06.007

Chincholi M, Sagwekar P, Nagaria C et al (2014) Removal of dye by adsorption on various adsorbents: a review. Int J Sci Eng Technol Res 3:835-840

Chiou M, Li H, Journal CE et al (2003) Minorities are under-represented in RCTs. BMJ. https://doi.org/10.1136/bmj.326.7401.0-d

Crini G, Badot PM (2008) Application of chitosan, a natural aminopolysaccharide, for dye removal from aqueous solutions by adsorption processes using batch studies: a review of recent literature. Prog Polym Sci 33:399-447

de Luna MDG, Murniati, Budianta W et al (2017) Removal of sodium diclofenac from aqueous solution by adsorbents derived from cocoa pod husks. J Environ Chem Eng 5:1465-1474. https://doi. org/10.1016/j.jece.2017.02.018

Dim PE (2013) Adsorption of methyl red and methyl orange using different tree bark powder. Acad Res Int 4:330-338

El Boujaady H, Mourabet M, Bennani-Ziatni M, Taitai A (2014) Adsorption/desorption of direct Yellow 28 on apatitic phosphate: mechanism, kinetic and thermodynamic studies. J Assoc Arab Univ Basic Appl Sci 16:64-73. https://doi.org/10.1016/j.jauba s.2013.09.001

Etim UJ, Umoren SA, Eduok UM (2016) Coconut coir dust as a low cost adsorbent for the removal of cationic dye from aqueous solution. J Saudi Chem Soc 20:S67-S76. https://doi.org/10.1016/j. jscs.2012.09.014

Godini K, Azarian G, Rahmani AR, Zolghadrnasab H (2013) Treatment of waste sludge: a comparison between anodic oxidation and electro-fenton processes. J Res Health Sci 13:188-193

Haldorai Y, Shim J (2014) An efficient removal of methyl orange dye from aqueous solution by adsorption onto chitosan/ $\mathrm{MgO}$ composite: a novel reusable adsorbent. Appl Surf Sci 292:447-453. https ://doi.org/10.1016/j.apsusc.2013.11.158

Harikumar P, Joseph L, Dhanya A (2013) Photocatalytic degradation of textile dyes by hydrogel supported titanium dioxide nanoparticles. J Environ Eng Ecol Sci 2:2. https://doi. org/10.7243/2050-1323-2-2

Hong G-B, Wang Y-K (2017) Synthesis of low-cost adsorbent from rice bran for the removal of reactive dye based on the response surface methodology. Appl Surf Sci 423:800-809. https://doi. org/10.1016/j.apsusc.2017.06.264

Iakovleva E, Sillanpää M, Maydannik P et al (2017) Manufacturing of novel low-cost adsorbent: co-granulation of limestone and coffee waste. J Environ Manag 203:853-860. https://doi. org/10.1016/j.jenvman.2017.05.039
Iovino P, Chianese S, Canzano S et al (2017) Photodegradation of diclofenac in wastewaters. Desalin Water Treat 61:293-297. https://doi.org/10.5004/dwt.2016.11063

Jawad AH, Mohd Ishak MA, Farhan AM, Ismail K (2017) Response surface methodology approach for optimization of color removal and COD reduction of methylene blue using microwave-induced $\mathrm{NaOH}$ activated carbon from biomass waste. Desalin Water Treat 62:208-220. https://doi.org/10.5004/dwt.2017.20132

Kumar M, Tamilarasan R (2013) Modeling of experimental data for the adsorption of methyl orange from aqueous solution using a low cost activated carbon prepared from Prosopis juliflora. Polish J Chem Technol 15:29-39. https://doi.org/10.2478/ pjct-2013-0021

Lin Q, Wang K, Gao M et al (2017) Effectively removal of cationic and anionic dyes by $\mathrm{pH}$-sensitive amphoteric adsorbent derived from agricultural waste-wheat straw. J Taiwan Inst Chem Eng 76:65-72. https://doi.org/10.1016/j.jtice.2017.04.010

Lu Y, Jiang B, Fang L et al (2016) High performance NiFe layered double hydroxide for methyl orange dye and $\mathrm{Cr}(\mathrm{VI})$ adsorption. Chemosphere 152:415-422. https://doi.org/10.1016/j.chemospher e.2016.03.015

Mi-na Z, Xue-pin L, Bi S (2006) Adsorption of surfactants on chromium leather waste. J Soc Leather Technol Chem 90:1-6

Mohammed Ma, Shitu A, Ibrahim A (2014) Removal of methylene blue using low cost adsorbent: a review. Res J Chem Sci 4:91-102

Munagapati VS, Yarramuthi V, Kim Y et al (2018) Removal of anionic dyes (Reactive Black 5 and Congo Red) from aqueous solutions using Banana Peel Powder as an adsorbent. Ecotoxicol Environ Saf 148:601-607. https://doi.org/10.1016/j.ecoenv.2017.10.075

Nandini R, Vishalakshi B (2012) A study of interaction of methyl orange with some polycations. E-Journal Chem 9:1-14. https:// doi.org/10.1155/2012/343928

Nilsson F (2015) Application of ozone in wastewater treatment. Int J ChemTech Res 5:139-147

Prakash NB, Sockan V, Jayakaran P (2014) Waste water treatment by coagulation and flocculation. Int J Sci Technol Res 3:479-484

Priyantha N, Lim LBL, Dahri MK (2015) Dragon fruit skin as a potential biosorbent for the removal of methylene blue dye from aqueous solution. Int Food Res J 22:2141-2148. https://doi. org/10.1136/bmj.326.7401.0-d

Rao MN, Rao YH, Chakrapani C, Babu CS (2011) Adsorption studies of methylene blue dye using prepared low-cost activated kaza's carbons. J Chem Pharm Res 3:363-375

Rashed MN (2013) Adsorption technique for the removal of organic pollutants from water and wastewater. In: Organic pollutants monitoring, risk and treatment. InTech, pp 167-194

Rattanapan S, Srikram J, Kongsune P (2017) Adsorption of methyl orange on coffee grounds activated carbon. Energy Procedia 138:949-954. https://doi.org/10.1016/j.egypro.2017.10.064

Rožič M, Senji IRA, Miljanić S (2014) Methylene blue sorption characterisation onto orange and lemon peels. Holist Approach Environ 4:97-110

Sangon S, Hunt AJ, Attard TM et al (2018) Valorisation of waste rice straw for the production of highly effective carbon based adsorbents for dyes removal. J Clean Prod 172:1128-1139. https://doi. org/10.1016/j.jclepro.2017.10.210

Sartape AS, Mandhare AM, Jadhav VV et al (2017) Removal of malachite green dye from aqueous solution with adsorption technique using Limonia acidissima (wood apple) shell as low cost adsorbent. Arab J Chem 10:S3229-S3238. https://doi.org/10.1016/j. arabjc.2013.12.019

Shakoor S, Nasar A (2017) Adsorptive treatment of hazardous methylene blue dye from artificially contaminated water using Cucumis sativus peel waste as a low-cost adsorbent. Groundw Sustain Dev 5:152-159. https://doi.org/10.1016/j.gsd.2017.06.005

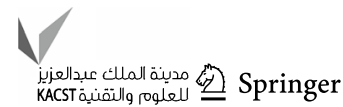


Skipton SO, Dvorak BI (2014) Drinking water treatment: Water softening (Ion Exchange). NebGuide Nebraska Ext Publ

Tizo MS, LA Blanco V, Cagas ACQ et al (2018) Efficiency of calcium carbonate from eggshells as an adsorbent for cadmium removal in aqueous solution. Sustain Environ Res 28:326-332. https://doi. org/10.1016/j.serj.2018.09.002

Vincenzo Naddeo AC (2013) Wastewater treatment by combination of advanced oxidation processes and conventional biological systems. J Bioremediation Biodegrad 04:308-312. https://doi. org/10.4172/2155-6199.1000208
Zhang Z, Luo X, Liu Y et al (2015) A low cost and highly efficient adsorbent (activated carbon) prepared from waste potato residue. J Taiwan Inst Chem Eng 49:206-211. https://doi.org/10.1016/j. jtice.2014.11.024

Publisher's Note Springer Nature remains neutral with regard to jurisdictional claims in published maps and institutional affiliations. 